\title{
EKSTRAK HEKSAN BIJI JINTAN HITAM (Nigella sativa $L$ ) MENINGKATKAN AKTIVITAS FAGOSITOSIS MAKROFAG TIKUS BETINA GALUR SD (Sprague Dawley) YANG DIINDUKSI DMBA (7,12Dimetilbenz(a)antrasen) SECARA IN VITRO
}

\author{
THE EFFECTS OF HEXANE EXTRACTS FROM BLACK CUMIN \\ SEEDS TO THE PHAGOCYTIC ACTIVITY OF MACROPHAGES SD \\ (Sprague Dawley) STRAIN FEMALE RATS BY DMBA \\ (7,12Dimetilbenz( $\alpha$ )antrasen) INDUCED IN VITRO
}

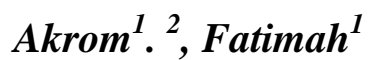 \\ ${ }^{1}$ Bagian Farmakologi dan Farmasi Klinik, Fakultas Farmasi UAD \\ 2. Pusat Informasi dan Kajian Obat, Universitas Ahmad Dahlan \\ Jl. Prof. Dr. Soepomo, Janturan, Yogyakarta \\ Email:akmaa_uad@yahoo.co.id
}

\begin{abstract}
ABSTRAK
Penelitian yang dilakukan sebelumnya telah membuktikan bahwa minyak biji jinten hitam bersifat sebagai imunomodulator, namun bagaimana mekanisme MBJH sebagai imunomodulator pada makrofag yang diinduksi DMBA belum diketahui. Telah dilakukan penelitian untuk mengetahui efek Ekstrak Hexana Biji Jinten Hitam (EHBJH) terhadap aktifitas fagositosis makrofag peritoneal tikus SD yang diinduksi DMBA. Penelitian ini dilakukan pada 10 ekor tikus betina Sprague Dawley yang dibagi dalam dua kelompok, yaitu 5 tikus kelompok tanpa perlakuan DMBA dan 5 tikus kelompok perlakuan DMBA. Setelah satu minggu pemberian DMBA sebanyak $15 \mathrm{mg}$ perekor tikus, tikus dibedah dan diambil cairan peritonealnya untuk dilakukan isolasi makrofag yang akan dikultur selama 24 jam. Makrofag peritoneal tersebut diberi ekstrak heksan BJH (Nigella sativa Lour) sebanyak $1 \mu \mathrm{g} / \mathrm{mL}, 5 \mu \mathrm{g} / \mathrm{mL}, 25 \mu \mathrm{g} / \mathrm{mL}$, dan diberi standar timokuinon untuk masing-masing kelompok tanpa induksi DMBA dan kelompok perlakuan DMBA. Makrofag diinkubasi kembali selama 2 jam. Uji fagositosis dilakukan dengan menambahkan partikel lateks pada makrofag berbudaya dan pewarnaan Giemsa. Data persentase jumlah makrofag yang makan lateks dan indeks fagositosis dianalisis dengan menggunakan uji Kolmogorov-Smirnov yang dilanjutkan dengan uji ANOVA dan uji LSD dengan taraf kepercayaan 95\%. Hasil penelitian menunjukkan bahwa aktifitas dan indek fagositosis makrofag yang tidak diinduksi DMBA lebih besar dari pada aktifitas dan indek fagositosis makrofag yang diinduksi makrofag ( $<<0,05)$. Kelompok $25 \mu \mathrm{g} / \mathrm{mL}$ EHBJH memiliki aktifitas dan indek fagositosis paling tinggi jika dibandingkan dengan kelompok perlakuan yang lain $(p<0,05)$. Kesimpulan penelitian menunjukkan bahwa ekstrak heksan BJH (Nigella sativa Lour) dapat meningkatkan aktivitas fagositosis makrofag tikus betina galur Sprague Dawley.
\end{abstract}

Kata kunci: ekstrak heksan, Nigella sativa L, fagositosis, makrofag

\begin{abstract}
Previous research has shown that black cumin seed oil is as an immunomodulator, but the mechanism MBJH as an immunomodulator in DMBA-induced macrophage unknown. A study to determine the effects of EHBJH on the activities of SD rat peritoneal macrophage phagocytosis induced DMBA has been conducted. This study was conducted on 10 female Sprague Dawley rats were divided into two groups, namely 5 mice without any treatment group and 5 mice DMBA DMBA treatment groups. Once a week administration of $15 \mathrm{mg}$ DMBA of mice,rats dissected and taken peritonealnya fluid for isolation of macrophages to be cultured for 24 hours. The peritoneal
\end{abstract}


macrophages were given hexane BJH (Nigella sativa Lour) as much as $1 \mathrm{mg} / \mathrm{mL}, 5 \mathrm{mg} / \mathrm{mL}, 25$ $\mathrm{mg} / \mathrm{mL}$, and were given a standard timokuinon for each group without induction DMBA and DMBA treatment groups. Macrophages were incubated for 2 hours back. Phagocytosis test is done by adding the latex particles on cultured macrophages and Giemsa staining. Data percentage of macrophages that eat latex and phagocytosis index were analyzed using the Kolmogorov-Smirnov test followed by ANOVA and LSD test with a 95\% confidence level. The results showed that the activity and phagocytosis index DMBA -induced macrophages that is not greater than the index of activity and macrophage phagocytosis induced macrophages ( $<<0.05$ ). A group of $25 \mathrm{mg} / \mathrm{mL}$ EHBJH have activity and phagocytosis index is highest when compared with the other treatment group $(\mathrm{p}<0.05)$. Conclusion: The study showed that the hexane BJH (Nigella sativa Lour) can improve macrophage phagocytic activity of female rats Sprague Dawley strain.

Keywords: hexane extract, Nigella sativa, macrophage, phagocytosis.

\section{PENDAHULUAN}

Sistem imun adalah semua mekanisme yang digunakan tubuh untuk mempertahankan keutuhan terhadap bahaya yang ditimbulkan berbagai bahan dalam lingkungan hidup (Harijanto, 2000). Senyawa yang bersifat imunosupresif seperti7,12-dimetilbenz $(\alpha)$ antrasen (DMBA) dapat melemahkan sistem imun. Senyawa 7,12-dimetilbenz $(\alpha)$ antrasen (DMBA) adalah zat kimia yang banyak terdapat di dalam asap dapur, kendaraan bermotor dan asap rokok, termasukdalam polycyclic aromatic hydrocarbon (PAH), dikenal bersifat mutagenik, teratogenik, karsinogenik, sitotoksik, dan immunosupresif. Kontaminasi DMBA biasa terjadi melalui makanan atau peroral, inhalasi maupun kontak kulit (Sitarina,2010). Enzim sitokrom P450 1A1 atau 1B1 (CYP1A1 atau CYP1B1) dan enzim microsomal hidrolase pada metabolisme fase I merubah DMBA menjadi DMBA-3,4-diol-1,2-epoksida (DMBA-DE) yang bersifat elektrofilik dan bersifat genotoksik dan imunosupresif. Eliminasi DMBA-DE dari tubuh dipercepat dengan adanya enzim antioksidan glutation-Stransferase (GST) (Gao et al., 2007). Penelitian baru-baru ini menunjukkan bahwa penghilangan sitokrom P450 1B1 (CYP1B1) dan mikrosoma epoksida hidrolase (MEH) oleh Gao et al., (2007 \& 2008) melindungi tikus terhadap imunosupresi sel limpa yang diproduksi oleh DMBA secara in vivo. Meningkatnya kejadian penyakit autoimun serta degenerative di masyarakat akhir-akhir ini diduga berkaitan dengan tingginya cemaran udara yang mengandung agen imunosupresansia seperti DMBA. Diperlukan agen imunostimulansia untuk mengimbangi agen imunosupresan yang masuk dalam tubuh.
Sistem imun dapat ditingkatkan dengan agen imunostimulansia. Pemanfaatan tanaman telah dilakukan manusia sejak berabad-abad yang lalu sebagai pengobatan (Tejasari, 2000). Salah satu jenis tanaman yang dimanfaatkan dalam pengobatan adalah jintan hitam. Salah satu khasiat dari biji jinten hitam (BJH) adalah sebagai imunomodulator, BJH dengan zat aktif utamanya timokuinon dapat meningkatkan kekebalan tubuh (Akrom, 2013; Salem, 2005). Pemberian secara oral minyak BJH pada hamster yang diinduksi streptozotocin (STZ) terbukti meningkatkan aktivitas fagositosis makrofag peritoneum danjumlah limfosit di dalam darah perifer dibandingkan hamster dengan diabetes yang tidak diberi MBJH (Salem,2005). Meskipun aktifitas imunomodulator BJH sudah banyak diteliti namun bagaimana pengaruh $\mathrm{BJH}$ in vitro terhadap efek imunosupresif DMBA belum diteliti.

Makrofag sebagai efektor sistem imun berperan memusnahkan kuman atau patogen yang akan merusak tubuh (Harijanto, 2000; Wijayanti, 2000). Melalui toll like receptor (TLR) makrofag dapat secara langsung kontak dengan pathogen termasuk imunogen dari tanaman sehingga menjadi aktif (Finley, 2010). Peningkatan aktifitas makrofag, ditandai dengan perubahan bentuk, perubahan biokimiawi, serta perubahan fungsi dari makrofag, merupakan salah satu parameter untuk menilai peningkatan sistem imun (Ulya, 2012; Baratawidjaja, 2006). Ekstrak heksan BJH yang banyak mengandung timokuinon dan asam lemak tak jenuh diduga dapat meningkatkan aktifitas fagositosis makrofag secara in vitro baik pada makrofag tikus yang tidak diinduksi maupun diinduksi DMBA. 


\section{METODE PENELITIAN}

\section{Bahan Penelitian}

Biji jintan hitam, ekstrak heksan BJH, heksan, PBS (phosphate buffered saline), FBS(fetal bovine serum), Giemsa, lateks, penstrep, fungison/amphoteracine, metanol, aquadest,RPMI, dan alkohol.

\section{Jalannya Penelitian}

\section{Pembuatan ekstrak heksan biji jinten hitam (EHBJH)}

Serbuk BJH seberat 500 gram dimaserasi dengan pelarut heksan sebanyak 1 liter selama 24 jam. Maserasi dilakukan bertingkat dengan masing-masing pelarut yang lebih sedikit dari pelarut pertama yaitu $750 \mathrm{~mL}$. Setelah didiamkan selama 1 malam kemudian diaduk dengan alat pengaduk elektrik selama setengah jam kemudian didiamkan lagi selama 1 malam, kemudian disaring dengan corong bucner dan filtratnya dipisah (maserat 1). Ampas dari hasil penyaringan maserat 1 kemudian ditambahkan lagi dengan heksan sampai serbuknya terendam semua, kemudian diaduk dengan alat pengaduk dan kemudian disaring ampasnya (maserat 2). Prosedur yang sama diulangi lagi hingga mendapatkan maserat 3. Ketiga maserat hasil penyarian kemudian dicampur, campuran maserat kemudian diuapkan pada rotary evaporator pada suhu $50^{\circ} \mathrm{C}$ sampai heksan tidak ada lagi yang menguap dan mendapatkan ekstrak kental. Ekstrak diuapkan dalam cawan petri dengan menggunakan waterbath. Ekstrak yang diperoleh disimpan dalam botol.

\section{Uji efek EHBJH terhadap aktifitas fagositosis makrofag}

Prosedur pelaksanaan uji efek EHBJH terhadap aktifitas fagositosis makrofag sesuai dengan prosedur yang dilakukan pada penelitian sebelumnya.

(i). Persiapan hewan uji.

Tikus betina galur SD berumur 1-2 bulan dipilih secara acak dibagi menjadi 2kelompok masing-masing 5 ekor. Kelompok I, kelompok tanpa pemberian perlakuan dengan DMBA dan kelompok II diberi DMBA $15 \mathrm{mg}$ perekor tikus secara intragastrik. Setelah pemberian DMBA selama 1 minggu kemudian tikus dibedah untuk diambil makrofag peritonealnya.

(ii). Pembuatan larutan uji EHBJH.

Larutan uji dibuat dengaan melarutkan ekstrak heksan seberat $25 \mathrm{mg}$ dalam tween 80 sebanyak 5 mikroliter, dan tambahkan dengan medium komplit (MK) 995 mikroliter dimasukkan dalam Eppendorf steril. Proses tersebut dilakukan di laminar air flow cabinet. Sehingga diperoleh larutan induk dengan konsentrasi $25 \mathrm{mg} / \mathrm{mL}$.

Kemudian dari larutan induk ini buat konsentrasi kadar dengan kadar $25 \mu \mathrm{g} / \mathrm{mL}$, $5 \mu \mathrm{g} / \mathrm{mL}$ dan $1 \mu \mathrm{g} / \mathrm{mL}$. Konsentrasi $25 \mu \mathrm{g} / \mathrm{mL}$ diambil 6,25 $\mu \mathrm{g}$, untuk konsentrasi $5 \mu \mathrm{g} / \mathrm{mL}$ diambil 1,25 $\mu \mathrm{g}$, dan untuk kadar $1 \mu \mathrm{g} / \mathrm{mL}$ diambil $0,25 \mu \mathrm{g}$ dari larutan induk yang kemudian masing-masing ditambahkan larutan MK sampai $5 \mathrm{~mL}$.

(iii). Pembuatan PBS sebagai larutan pencuci.

Larutan PBS terdiri dari $\mathrm{NaCl} 8$ gram, KH2PO4 0,1 gram dan NaHPO4 2,9 gramdilarutkan ke dalam aquadest 1 liter diaduk sampai semua serbuk terlarut, dibuat $\mathrm{pH} \quad 7,2$ jikaterlalu asam ditambah larutan $\mathrm{NaOH} 1 \mathrm{~N}$ dan jika terlalu basa ditambahkan aquades sampailL. Larutan disimpan dalam almari es di dalam botol tertutup (Anonim, 1998).

(iv). Isolasi dan kultur makrofag.

Isolasi makrofag dilakukan dengan menggunakan metode yang digunakan oleh Akrom(2013). Kesepuluh tikus di bunuh dengan narkose menggunakan kloroform. Tikus diletakkan dalam posisi terlentang, kulit bagian perut dibuka dan dibersihkan selubung peritoniumnya dengan alkohol $70 \%$, kemudian disuntikkan 10 mlmedium RPMI dingin kedalam rongga peritoneum, ditunggu selama tiga menit sambil digoyang-goyang perutnya secara perlahan. Selanjutnya cairan peritoneum dikeluarkan dari rongga peritoneum dengan cara menekan rongga dalam dengan dua jari, cairan diaspirasi. Dengan spuit injeksi, dipilih pada bagian yang tidak berlemak dan jauh dari usus. Cairan peritonium dari masing-masing tikus tersebut dimasukkan dalam dua plate/tabung yang berbeda yaitu satu plate/tabung kelompok diinduksi DMBA dan satu plate/tabung untuk kelompok tak diinduksi DMBA.

(a). Penghitungan sel viabel. Sel makrofag yang sudah diisolasi dan viable yang akan dilakukan kultur perlu ditetapkan jumlahnya. Prosedur perhitungan sel makrofag secara ringkas adalah 
sebagai berikut: dek gelas dibersihkan dengan tisu beralkohol, kemudian dipasangkan pada alat sesuai dengan ukuran tempat, cairan makrofag diaduk, cairan dimasukkan dalam tabung steril, diambil dengan pipet ke alat haematocytometer dan ditentukan viabilitasnya dengan larutan trypan blue kemudian dibaca menggunakan alat microscope inverted dengan perbesaran 100 kali.

(b). Kultur makrofag dan uji aktifitas fagositosis makrofag. Suspensi sel ditumbuhkan dalam mikrokultur 24 sumuran yang telah diberi coverslips bulat. Setiap sumuran diisi $1 \mathrm{~mL}$ yang mengandung $5 \times 10^{5}$ sel. Sel diinkubasikan dalam inkubator $\mathrm{CO} 25 \%$ selama 24 jam (Akrom, 2013). Setelah diinkubasi selama 24 jam, media dibuang dan ditambahkan $1 \mathrm{~mL}$ sampel uji yaitu $25 \mu \mathrm{g} / \mathrm{mL}, 5 \mu \mathrm{g} / \mathrm{mL}$ dan $1 \mu \mathrm{g} / \mathrm{mL}$ EHBJH sesuai dengan kelompok. Kelompok 1 untuk diberi EHBJH konsentrasi $1 \mu \mathrm{g} / \mathrm{mL}$, kelompok 2 diberi EHBJH konsentrasi $5 \mu \mathrm{g} / \mathrm{mL}$, kelompok 3 diberi EHBJH konsentrasi $25 \mu \mathrm{g} / \mathrm{mL}$, kelompok 4 sebagai kontrol positif diberi timokuinon standar, dan kelompok 5 sebagai kontrol medium diberi RPMI.

Uji fagositosis dilakukan secara in vitro, dilakukan sesuai prosedur yang digunakan pada penelitian sebelumnya (Akrom, 2013). Sel yang sudah diberi sampel dan diinkubasi dalam $\mathrm{CO}_{2}$ $5 \% 37^{\circ} \mathrm{C}$ selama $1 \mathrm{jam}$. Kemudian supernatan dibuang dan dicuci 2 kali dengan RPMI. Pencucian diulangi kembali dengan menggunakan PBS 3x sebanyak 500 mikroliter/sumuran. Setelah bersih kemudian sel makrofag selanjutnya diinkubasi selama $1 \mathrm{jam}$.

Fiksasi dilakukan dengan menambahkan pada masing-masing micro plate (sumuran) dengan 100 mikroliter metanol absolut. Fiksasi dilakukan selama 30 detik. Setelah difiksasi kemudian kultur makrofag dikeringkan dengan kipasangin kembali dan ditambahkan $200 \mu \mathrm{L}$ Giemsa $20 \%$ pada sumuran yang telah dikeringkan. Setelah itu, didiamkan pada suhu kamar \pm 20 menit kemudian sisa Giemsa dibuang dan dicuci dengan air mengalir tetapi tidak sampai bersih dan kemudian dikeringkan dengan kipas angin. Coverslip pada masing-masing sumuran diambil dan diletakkan di atas objek glass dan diamati. Selanjutnya diamati dengan mikroskop dan akan terlihat lateks yang berwarna putih dan makrofag berwarna ungu. Presentase sel makrofag yang memfagositosis partikel lateks yang difagositosis dihitung minimal 100 sel diperiksa dengan mikroskop cahaya perbesaran 400x (Akrom, 2013).

\section{Analisis data}

Analisis data menggunakan uji Kolmogorov-Smirnov yang dilanjutkan dengan uji ANOVA dan uji LSD dengan taraf kepercayaan $95 \%$.

\section{HASIL DAN PEMBAHASAN}

\section{Pembuatan ekstrak heksan biji jinten hitam}

Hasil penyarian dengan metode maserasi dengan pelarut heksan diperoleh EHBJH dengan rendemen sebesar 26,44\%. Dari bahan awal seberat 500 gram dan diperoleh bobot ekstrak 132,18 gram. Secara makroskopis EHBJH berwarna hijau gelap, berminyak dan berbau khas minyak atsiri.

\section{Uji efek EHBJH terhadap aktivitas fagositosis makrofag}

Uji daya aktivitas fagositosis dilakukan menggunakan metode iv vitro. Keunggulan metode in vitro yaitu waktu yang digunakan lebih singkat, biaya lebih murah serta penggunaan sempel yang digunakan lebih sedikit apabila dibandingkan in vivo. Selain ituproses fagositosis yang terjadi dapat di amati secara langsung (Miksusanti, 2010). Kelemahan in vitro adalah media yang digunakan kondisinya tidak mesti sama dengan yang digunakan dalam metode in vivo (Nurcholis, 2011).

Kemampuan fagositosis makrofag diukur dengan melihat seberapa besar kemampuan makrofag memakan lateks, yaitu dengan menghitung persentase jumlah makrofag yang makan lateks pada setiap kelompok perlakuan serta menghitung indeks fagositosisnya. Aktifitas fagositosis makrofag ditunjukan pada Gambar 1:

Partikel lateks yang terpejan dengan fagosit akan ditangkap dan ditelan denganbantuan reseptor pada membran sel pada gambar di atas. Hasil perhitungan persentase 
jumlah makrofag yang makan lateks pada setiap kelompok dapat dilihat pada Tabel I.

Dari hasil perhitungan pada Tabel I diketahui bahwa persentase fagositosis makrofag tikus tak diinduksi DMBA lebih tinggi jika dibandingkan dengan tikus yang diinduksi DMBA $(\mathrm{p}<0,05)$. Makrofag yang diinduksi DMBA mengalami penurunan aktifitas fagositosis, hal ini dapat disebabkan karena hasil metabolit DMBA yang berupa DMBA-DE dapat berikatan dengan DNA dan menyebabkan kerusakan DNA dengan membentuk adduct dengan basaguanin dalam DNA sehingga menimbulkan kerusakan sel dan dapat menurunkan aktivitas fagositosis makrofag peritoneal (Gao et al, 2008; 2007).

Urutan kemampuan fagositosis berdasarkan persentase jumlah makrofag yang makanlateks dari yang terkecil sampai terbesar pada tikus tanpa induksi DMBA adalah: control negatif, konsentrasi $1 \mu \mathrm{g} / \mathrm{mL}, 5 \mu \mathrm{g} / \mathrm{mL}, 25 \mu \mathrm{g} / \mathrm{mL}$ dan yang terakhir adalah kontrol positif (timokuinon). Kemudian untuk urutan kemampuan fagositosis berdasarkan persentase jumlah makrofag yang makan lateks dari yang terkecil sampai yang terbesar pada tikus yangdiinduksi DMBA adalah: kontrol negatif, konsentrasi $1 \mu \mathrm{g} / \mathrm{mL}, 5 \mu \mathrm{g} / \mathrm{mL}, 25 \mu \mathrm{g} / \mathrm{mL}$ dan yangterakhir adalah kontrol positif (timokuinon).
Hasil perhitungan indek fagostosis makrofag peritoneal tikus SD yang diinduksi DMBA atau tak dinduksi DMBA dengan pemberian EHBJH disajikan pada Tabel II.

Hasil penelitian menunjukkan bahwa indek fagositosis makrofag tikus SD yang tak diinduksi DMBA lebih tinggi dari pada indek fagositosis makrofag tikus SD yang diinduksi DMBA $(\mathrm{p}<0,05)$. Kelompok $25 \mu \mathrm{g} / \mathrm{mL}$ EHBJH memiliki indek fagositosis tertinggi dibandingkan dengan kelompok yang lain. Sedangkan urutan kemampuan fagositosis berdasarkan indeks fagositosisnya dari yang terkecil sampai terbesar pada tikus tanpa induksi DMBA adalah: kontrol negatif, konsentrasi $1 \mu \mathrm{g} / \mathrm{mL}, 5 \mu \mathrm{g} / \mathrm{mL}, 25$ $\mu \mathrm{g} / \mathrm{mL}$ dan yang terakhir adalah kontrol positif (timokuinon). Kemudian untuk urutan kemampuan fagositosis berdasarkan nilai indeks fagositosis dari yang terkecil sampai yang terbesar pada tikus yang diinduksi DMBA adalah: konsentrasi $1 \mu \mathrm{g} / \mathrm{mL}$, kontrol negatif, $5 \mu \mathrm{g} / \mathrm{mL}, 25 \mu \mathrm{g} / \mathrm{mL}$ dan yang terakhir adalah kontrol positif (timokuinon). Hasil penelitian menunjukkan bahwa kemampuan makrofag dalam memfagositosis lateks semakin meningkat dengan penambahan timokuinon serta semakin besar kadar timokuinon maka semakin besar pula kemampuan fagositosis dari makrofag.

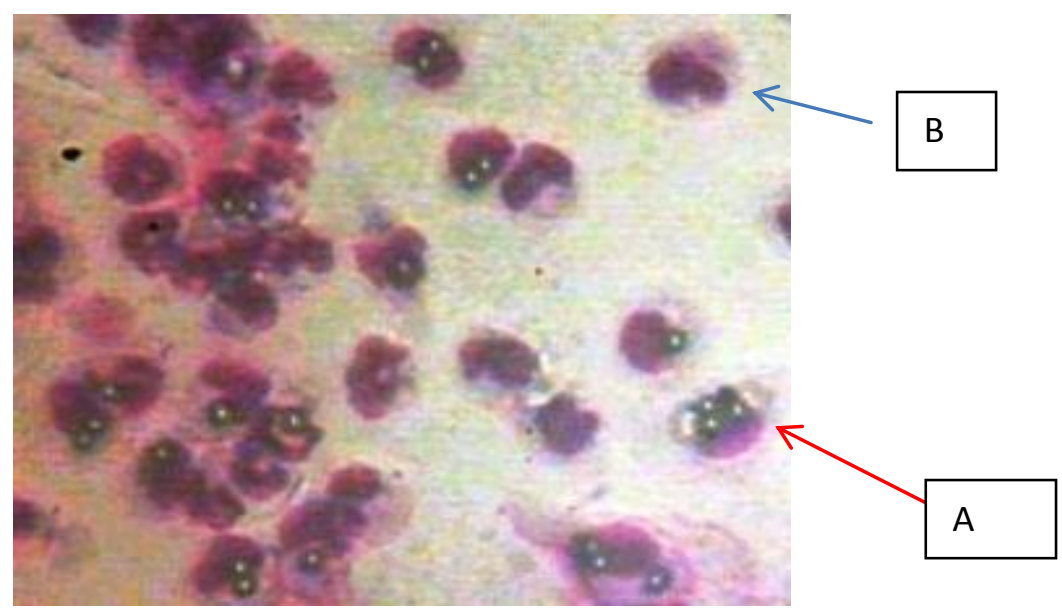

Gambar 1. Aktifitas fagositosis makrofag peritoneal tikus SD yang diinduksi DMBA atau tak diinduksi DMBA dengan pemberian EHBJH secara in vitro. Makrofag dicat dengan Giemsa dibaca pada perbesaran 10x10. $A=$ makrofag yang memfagositosis latek; $\quad B=$ makrofag yang tidak memfagositosis latek 
Tabel I. Persentase fagositosis makrofag peritoneal tikus SD diinduksi DMBA dan tak diinduksi DMBA setelah diberi EHBJH

\begin{tabular}{cccc}
\hline Kelompok Perlakuan & \multicolumn{2}{c}{$\begin{array}{c}\text { Persentase fagositosis makrofag } \\
\text { peritoneal tikus SD } \\
\text { Tak diinduksi } \\
\text { DMBA }\end{array}$} & $\begin{array}{c}\text { Selisi persentase fagositosis } \\
\text { makrofag yang diinduksi \& } \\
\text { tak diinduksi DMBA }\end{array}$ \\
\hline $1 \mu \mathrm{g} / \mathrm{mL}$ & $54,93 \pm 3,52^{\mathrm{a}}$ & $51,37 \pm 4,35^{*^{\mathrm{a}}}$ & $3,56 \pm 0,20$ \\
$5 \mu \mathrm{g} / \mathrm{mL}$ & $57,34 \pm 0,88^{*^{\mathrm{a}}}$ & $52,71 \pm 2,49^{*^{\mathrm{a}}}$ & $4,63 \pm 0,34$ \\
$25 \mu \mathrm{g} / \mathrm{mL}$ & $56,46 \pm 3,83^{*^{\mathrm{a}}}$ & $55,38 \pm 1,32^{*^{\mathrm{a}}}$ & $1,08 \pm 0,32$ \\
Timokuinon & $63,33 \pm 3,83^{*}$ & $59,93 \pm 2,82^{*}$ & $3,40 \pm 0,21$ \\
Medium & $47,94 \pm 0,03^{\mathrm{a}}$ & $45,56 \pm 1,88^{\mathrm{a}}$ & $2,38 \pm 0,24$ \\
\hline
\end{tabular}

Ket: $*=p<0,05$ uji beda rata-rata terhadap kelompok medium; $a=p<0,05$ uji beda rata-rata terhadap timokuinon

Tabel II. Indek fagositosis makrofag peritoneal tikus SD yang diinduksi dan tak diinduksi DMBA dengan pemberian EHBJH

\begin{tabular}{lccc}
\hline Kelompok Perlakuan & $\begin{array}{c}\text { indeks fagositosis makrofag peritoneal } \\
\text { Tak diinduksi } \\
\text { DMBA }\end{array}$ & $\begin{array}{c}\text { Selisi indeks fagositosis } \\
\text { Diinduksi DMBA }\end{array}$ & \\
\hline $1 \mu \mathrm{g} / \mathrm{mL}$ & $2,44 \pm 0,18^{*^{\mathrm{a}}}$ & $1,71 \pm 0,136$ & $0,73 \pm 0,12^{*}$ \\
$5 \mu \mathrm{g} / \mathrm{mL}$ & $2,54 \pm 0,01^{*^{\mathrm{a}}}$ & $2,08 \pm 0,05^{*}$ & $0,46 \pm 0,10^{*}$ \\
$25 \mu \mathrm{g} / \mathrm{mL}$ & $2,91 \pm 0,26^{*}$ & $2,21 \pm 0,096^{*}$ & $0,70 \pm 0,13^{*}$ \\
Timokuinon & $2,71 \pm 0,44^{*}$ & $2,11 \pm 0,015^{*}$ & $0,60 \pm 0,23^{*}$ \\
Medium & $1,70 \pm 0,04$ & $1,86 \pm 0,075$ & $0,16 \pm 0,21$ \\
\hline
\end{tabular}

Ket: $*=\mathrm{p}<0,05$ uji beda rata-rata terhadap kelompok medium; $\mathrm{a}=\mathrm{p}<0,05$ uji beda rata-rata terhadap timokuinon

Tujuan dari pemberian induksi DMBA adalah untuk membandingkan kemampuan fagositosis tikus tanpa induksi DMBA dan tikus yang diinduksi DMBA serta untuk mengetahui kemampuan EHBJH dalam meningkatkan kemampuan fagositosis makrofag hingga memiliki kemampuan yang setara dengan kondisi tanpa induksi DMBA. Kelompok perlakuan diberikan DMBA sebesar $15 \mathrm{mg}$ per ekor tikus.Tikus tanpa induksi DMBA maupun tikus yang diinduksi DMBA dibedah satu minggu setelah pemberian DMBA, untuk diambil makrofag peritonealnya yang kemudian dikultur selama 24 jam. Setelah 24 jam makrofag peritoneal tersebut diberi EHBJH (Nigella sativa Lour) dan standar timokuinon sesuai dengan kelompoknya yaitu kelompok konsentrasi 1 $\mu \mathrm{g} / \mathrm{mL}, 5 \mu \mathrm{g} / \mathrm{mL}, 25 \mu \mathrm{g} / \mathrm{mL}$, kontrol positif yang diberi standar timokuinon, dan kontrol negatif yang tidak diberi EHBJH maupun standar timokuinon (Akrom, 2013).

Penambahan timokuinon dapat meningkatkan aktivitas fagositosis karena timokuinon menginduksi enzim neu4 sialidase yang berperan dalam mekanisme aktivasi makrofag. Neu4sialidse berperan dalam hantaran respon dari TLR4 menuju makrofag yaitu meningkatkankompleks antara TLR4 dan myd88 (Finlay et al, 2010). TLR4 merupakan reseptor ada dipermukaan makrofag, sinyal dari TLR mengakifkan respon imun non spesifik, cirinya yaitu merangsang produksi faktor transkripsi yang menghasilkan produksi berbagai protein dan makrofag melepas sejumlah sitokin yang berperan dalam respon imun (Baratawidjaja, 2006).

Seperti yang sudah dikemukakan bahwa biji Nigella sativa memiliki komposisi kimia terdiri dari $32-40 \%$ minyak, $0,4-0,45 \%$ minyak atsiri yang berupa timokuinon (Akrom, 2013). Timokuinon larut dalam kloroform, PE, dan heksan. Berdasarkan penelitian Ashraf et al (2011) ektrak heksan BJH terbukti mengandung timokuinon sebanyak $248 \mathrm{mg} / \mathrm{g}$ ekstrak. Kandungan senyawa dari BJH yaitu timokuinon memiliki efek menginduksi enzim Neu4 sialidase yang berperan dalam aktivasi transduksi sinyal reseptor TLR4 makrofag (Finlay, 2010). Neu4 sialidase berperan meningkatkan myd88 yangberikatan kompleks dengan TLR4 yang 
nantinya akan menginduksi faktor transkripsi dan mengaktivasi makrofag (Akira, 2003).

\section{KESIMPULAN}

Pemberian EHBJH (Nigella Sativa Lour) dapat meningkatkan aktifitas fagositosis makrofag tikus betina galur SD yang diinduksi DMBA secara invitro.

\section{UCAPAN TERIMA KASIH}

Ucapan terima kasih dan penghargaan yang setinggi-tingginya diberikan kepada Ford Foundation, melalui program Indonesian Scholar Dissertation Award (ISDA), telah bersedia membiayai penelitian disertasi yang penulis ajukan.

\section{DAFTAR PUSTAKA}

Akira, Shizuo., 2003, Toll-like Receptor Signaling, The Journal Of Biological Chemistry,Vol. 278: 38105-38108.

Akrom, 2013. Ekanisme kemopreventive MBJH pada tikus Sprague dawley (SD) yang diinduksi 7,12 dimethylbenza(a) antracene (DMBA), Disertasi, Pasca Sarjana, UGM, Yogyakarta.

Ashraf, S.S., Rao, M.V., Kaneez, F.S., Qadri, S., Al-Marzouqi, A.H., Chandranath, I.S., Adem, A.., 2011, Nigella sativa Extract as a Potent Antioxidant for Petrochemical-InducedOxidative Stress, Journal of Chromatographic Science, Vol. 49.

Badr, G., Mohany, M., Abu-Tarboush, F.., 2011, Thymoquinone decreases F-actin polymerization and the proliferation ofhuman multiple myeloma cells by suppressing STAT3 phosphorylation an Bcl2/Bcl-XLexpression, Lipids in Health and Disease, 10:236.

Baratawidjaja., K. G., 2006, Imunologi Dasar edisi keempat, Balai Penerbit FakultasKedokteran UI, Jakarta.

Finlay, T. M., Abdulkhalek, S., Gilmour, A., Guzzo, C., Jayanth, P., Amith, S. R.,. Szewczuk, M. R, 2010, Thymoquinone- induced Neu4 sialidase activates NFkappaB in macrophage cells and proinflammatory cytokines in vivo. Glycoconj J, 27(6), 583-600. doi: 10.1007/s10719-010-9302-5.

Gao, J., Lauer, F.T., Mitchell, L.A., Burchiel, S.W..., 2007, Microsomal expoxide hydrolase is required for 7,12dimethylbenz[a]anthracene (DMBA) induced immunotoxicity in mice. Toxicol Sci,98:137-144.

Gao, J., Mitchell, L.A., Lauer, F.T., Burchiel, S.W.., 2008, p53and ATM/ATR Regulate $7,12-$

Dimethylbenz(a)anthracene

InducedImmunosuppression, Molecular Pharmacology, 73:137.

Harijanto, P. N. (ed)., 2000, Malaria epidemiologi, Patogenesiss, Manifestasi Klinis danPenanganannya, ECG, Jakarta.

Miksusanti, 2010, Proliferasi Sel Limfosit Secara In Vitro oleh Minyak Atsiri Temu Kuncidan Film Edibel Anti Bakteri, Jurnal Penelitian Sains, 10:06-07.

Nurcholis, Mochamad, dan Zubaidah., E., 2011, Evaulasi In Vivo Efek Sinobiotik BekatulTerfermentasi Bakteri Asam Laktat Probiotik (Lactobacillus plantarum B2 dan Lactobacillus casei), Jurnal Teknologi Pertanian, 58-67.

Salem, M. L., 2005, Immunomodulatory and Therapeutic Properties of The Nigella sativa L.seed, International Immunopharmacology, 5:1749-1770.

Tejasari., 2000, Efek Proteksi Komponen Bioaktif Oleoresin Rimpang Jahe (Zingiberofficinale Roscoe) Terhadap Fungsi Limfosit Secara In Vitro, Disertasi. ProgramPascasarjana, IPB, Bogor.

Ulya, A.N., 2012, Efek Peningkatan Aktivitas Fagositosis Makrofag Fraksi KloroformEkstrak Etanol Kelopak Rosella (Hibiscus ssabdarifa L) secara in 
vitro, Skripsi,Fakultas Farmasi, UAD, Yogyakarta.

Sitarina., W., dan Budi, R.T., 2010, Dampak Induksi Karsinogenesis Glandula Mammae dengan $7, \quad 12-$ dimetilbenz(a)antrasen terhadap Gambaran Histopatologis lambung Tikus Sprague Dawley, Jurnal Veteriner ISSN: 1411-8327.

Wijaya, A., 2007, Pengaruh Pemberian Ekstrak Etanol Biji Jinten Hitam (Nigella sativa,Lour) Terhadap Aktivitas Fagositosis Makrofag Mencit Jantan Galur Swiss SetelahInfeksi Listeria monocytogenes Secara In Vitro, Sripsi, Fakultas Farmasi, UAD, Yogyakarta

Wijayanti, M.A., 2000, Sekresi reactive oxgen intermediates oleh makrofag peritoneummencit yang diimunisasi selama infeksi Plasmodium berghei, BIK, 32,2:77-82. 